\title{
Lake-Groundwater Relationships and Fluid-Rock Interaction in the East African Rift Valley: Isotopic Evidence
}

\author{
W George Darling ${ }^{1}$, Berhanu Gizaw ${ }^{2}$ and Musa K Arusei ${ }^{3}$ \\ ${ }^{1}$ British Geological Survey, Wallingford OX10 8BB, UK \\ ${ }^{2}$ Ethiopian Institute of Geological Surveys, PO Box 40069, Addis Ababa, Ethiopia \\ ${ }^{3}$ Moi University, PO Box 3900, Eldoret, Kenya
}

\begin{abstract}
The assessment of water resources in the Rift Valley environment is important for population, agriculture and energy-related issues, and depends on a good understanding of the relationship between freshwater lakes and regional groundwater. This can be hampered by the amount of fluid-rock interaction which occurs throughout the Rift, obscuring original hydrochemical signatures. However, oxygen and hydrogen stable isotope ratios can be used as tracers of infiltration over sometimes considerable distances, while showing that the volcanic edifices of the Rift floor have varying effects on groundwater flow patterns. Specific cases from Kenya and Ethiopia are considered, including Lakes Naivasha, Baringo, Awasa and Zwai.

In addition to their physical tracing role, stable isotopes can reveal information about processes of fluid-rock interaction. The general lack of oxygen isotope shifting in Rift hydrothermal systems suggests a high water:rock ratio, with the implication that these systems are mature. Carbon isotope studies on the predominantly bicarbonate waters of the Rift show how they evolve from dilute meteoric recharge to highly alkaline waters, via the widespread silicate hydrolysis promoted by the flux of mantle carbon dioxide which occurs in most parts of the Rift. There appear to be only minor differences in this carbon cycle between Kenya and Ethiopia.
\end{abstract}

\section{INTRODUCTION}

Hydrochemistry often provides an effective way of discriminating between different groundwater sources and assessing the amount of any mixing between them. Typical examples of this would be coastal intrusion by sea water or, on a smaller scale, the 
interaction between landfill contamination plumes and the regional aquifer. However, in situations where a large amount of fluid-rock interaction is occurring, the original chemical characteristics of one or more of the end members of any mixing may be obscured, making it difficult or impossible to ascribe water origins or the amount of mixing.

One area where there is an abundance of such fluid-rock interaction is the East African Rift System. In this area, the effective management of groundwater resources is important not only for potable water supply and agriculture, but also in connection with the exploitation of geothermal energy. Each use requires a good understanding of water movement in the subsurface, but conventional hydrochemical techniques are not always easy to apply in the Rift environment. Oxygen and hydrogen stable isotopes, on the other hand, are ideally suited to this environment because of the amount of interaction between ground and surface waters. This mainly takes the form of infiltration from lakes to groundwater, where the characteristic isotopic signature imparted by surface evaporation makes a highly effective tracer of subsequent flow into the regional aquifer system.

Stable isotopes can act as chemical as well as physical tracers. Nearly all waters in the Rift Valley are of sodium-bicarbonate type, in certain cases reaching very high concentrations. The study of carbon isotope ratios in these waters helps to explain their origin and evolution.

This paper presents some new stable isotopic data for the East African Rift Valley from Kenya and Ethiopia. The main focus for oxygen and hydrogen isotopes is on the freshwater lakes of the Rift Valley, while carbon isotopes are considered on a more regional scale.

\section{SAMPLING AND ANALYSIS}

Water samples for $\mathrm{O}$ and $\mathrm{H}$ stable isotopic analysis were collected from springs, boreholes, geothermal wells, and boreholes drilled for temperature gradient studies. They were stored in $28 \mathrm{ml}$ glass bottles with rubber-lined metal caps (McCartney type) prior to analysis. Samples of water for analysis of C stable isotopes were collected in $250 \mathrm{ml}$ glass bottles, in which the dissolved inorganic carbon (DIC) was precipitated by treatment with alkaline $\mathrm{BaCl}_{2}$. The resulting precipitates were washed with deionised water and dried. 
Samples were prepared for ${ }^{18} \mathrm{O} /{ }^{16} \mathrm{O}$ and ${ }^{2} \mathrm{H} /{ }^{1} \mathrm{H}$ analysis by the methods of Epstein and Mayeda (1953) and Coleman et al. (1982) respectively. For ${ }^{13} \mathrm{C} /{ }^{12} \mathrm{C}$, dissolution of the dried $\mathrm{BaCO}_{3}$ precipitates with anhydrous $\mathrm{H}_{3} \mathrm{PO}_{4}$ was used to yield $\mathrm{CO}_{2}$ gas for analysis. Isotope ratio measurements were carried out on VG 602E and Optima mass spectrometers at BGS Wallingford.

\section{LAKE-GROUNDWATER RELATIONSHIPS}

One of the features of the Kenya Rift Valley (KRV) and the Main Ethiopian Rift (MER) is the chain of lakes occupying the valley floors (Fig. 1). The existence of these lakes is at least partly due to the numerous late-Quaternary central volcanic structures which often separate the lakes from each other (Fig. 1). The relationships between these lakes and regional groundwaters vary considerably, with the result that the lakes range from fresh to highly alkaline in their chemistry. Because the highly alkaline lakes are discharge areas their relationships with regional waters are fairly clear and of less significance in terms of groundwater resource management. In the case of the fresher lakes, however, and particularly where there is no surface egress, relationships with groundwater are not so apparent, but of much more importance to the assessment of resources. The cases considered here are concerned with this type of lake.

\section{Lake Naivasha area, Kenya}

Lake Naivasha (Figs. 1,2) has been suspected for at least 60 years of significant subsurface leakage (Sikes, 1935). Most attempts at assessing its water balance have arrived at an annual loss of tens of millions of cubic metres to the subsurface. Owing to its situation on the culmination on the floor of the updomed KRV, potential exists for leakage to occur in both northerly and southerly directions. Darling et al. (1990) used stable isotopic techniques to show that lakewater appeared to be detectable at least $30 \mathrm{~km}$ to the south at the Suswa volcano (Fig. 2). The new data presented here have been obtained from deep ( $2000 \mathrm{~m})$ wells drilled in the Olkaria and Eburru geothermal fields, respectively to the SW and NW of the lake (Fig 2).

It has been considered for some time that the currently-producing Olkaria East wellfield 
might be obtaining at least some of its water from Naivasha. Darling et al. (1990) showed that the reservoir fluid could be explained by a 2:1 mixture of lakewater with unmodified meteoric recharge from the rift wall area. Logically, therefore, it would be expected that the newer exploration area of Olkaria Northeast, which is nearer to the lake, would have a higher proportion of lakewater. The $\delta$-plot of Fig. 3 (based on the data in Table 1) shows that this is partly the case. Well OW-706 seems to be too far to the west side of the lakewater plume to show a result significantly different to the main wellfield, but OW-705 and OW-703 show the anticipated northerly increase. However OW-715, slightly nearer to the lake even than OW-703, shows much less of a lake water contribution. Since it is situated adjacent to the prominent NW-trending Gorge Farm Fault, the well may be affected by a large input of meteoric water.

Isotopic evidence from the Eburru well EW-1 (Figs. 2 and 3, Table 1) shows that lakewater also passes beneath the Eburru volcanic ridge. When depth sample data from EW-1 are plotted against depth (Fig. 4), a peak is seen at $1850 \mathrm{~m}$ below surface. This tends to support the evidence from OW-715 that local fissuring or faulting can have quite marked effects on local fluid compositions.

\section{Lake Baringo area, Kenya}

In the northern KRV, Lake Baringo is a freshwater lake with no surface outlet. Only slightly larger than Naivasha, it seems likely to have a subsurface outflow of the same order as that lake to preserve its chemical balance. Unlike Naivasha, however, any output from Baringo would have to be directed exclusively to the north on hydrogeological grounds (Allen and Darling, 1992). The perennial hot $\left(\sim 50^{\circ} \mathrm{C}\right)$ springs of Kapedo, west of the Silali Volcano (Fig. 5) have an output comparable in volume to the loss estimated for the lake, and it was the view of investigators such as WRAP (1987) that the springs consist essentially of lakewater. The $\delta$-plot of Fig. 6 shows that on isotopic grounds lakewater could only be contributing up to $30 \%$. This could not have been resolved by chemical measurements; the TDS at Kapedo is far higher than those of the lake or rift-wall source water represented by borehole C3470 (Allen and Darling, 1992). This also applies to the Lorusio hot springs some $10 \mathrm{~km}$ to the north of Kapedo (Fig. 5). These springs, with a higher temperature $\left(\sim 80^{\circ} \mathrm{C}\right)$ and about double the TDS content, show no sign whatever of a lakewater 
component (Fig. 6).

\section{Lake Awasa area, Ethiopia}

The freshwater Lake Awasa in the MER (Fig. 1) is also similar in size to Naivasha. While no detailed estimates of its subsurface outflow have been published, it seems likely to be of the same order as Naivasha. Table 2 gives relevant stable isotope data for the area, including some steam condensate values obtained from fumaroles associated with the nearby Corbetti caldera (Fig.7). The $\delta$-plot in Fig. 8 shows strong evidence that there is a northward flow from Awasa with around 50\% lake water outside the caldera to the $\mathrm{E}$ and $\mathrm{NE}$ at the temperature-gradient boreholes TG-7 and TG-3, but considerably less to the north at Koka, where assuming a $\delta^{18} \mathrm{O}$ fractionation between fumarolic steam and parent water of around $2 \%$, there might be $\sim 15-20 \%$ of lake water underlying the area. A similar amount is indicated for the Borama fumarole immediately outside the caldera. By contrast, it appears that there is little or no lake water beneath the caldera, even allowing for the possibility of steam heating or subsurface steam condensation making the parent water in the caldera appear somewhat more isotopically depleted than it actually is. The Corbetti caldera is a much better-defined ring structure than the Olkaria or Eburru eruptive centres, and may therefore form a more significant barrier to the passage of lakewater into the hydrothermal plumes beneath the volcanoes within the caldera.

\section{Zwai-Langano area, Ethiopia}

The Aluto volcanic centre between Lakes Zwai and Langano (Fig. 1) has a ring-like structure intermediate in definition between those of Corbetti and Olkaria. Unlike Corbetti, it has the advantage of deep geothermal wells drilled within the complex (the Aluto-Langano geothermal field) from which fluid samples were obtained. In addition there are fumarolic areas and temperature gradient boreholes which also yielded samples. Stable isotope values are given in Table 3 .

The difference in altitude between Lake Zwai at $\sim 1636 \mathrm{~m}$ and Lake Langano at $\sim 1582 \mathrm{~m}$ above sea level provides potential for subsurface leakage southward between the lakes, conceivably beneath Aluto (Fig. 9). However, the $\delta$-plot in Fig 10 reveals that the lakewater 
content beneath the centre cannot exceed $10 \%$, with the deep wells having values much more similar to the rift-side isotopic composition than to the highly-evaporated and isotopically enriched water of Zwai. (The small shifts in $\delta^{18} \mathrm{O}$ shown by wells LA-4 and LA-6 may be due to water-mineral exchange, but at least some of the isotopic enrichment in LA-4 is likely to be due to the effects of steam separation within the reservoir.) This implies that Lake Zwai plays little or no part in the Aluto hydrothermal circulation, an important conclusion regarding the assessment of geothermal resources.

The greater amount of lakewater $(\sim 20 \%)$ indicated by the two temperature gradient wells south of the Aluto-Langano wellfield may be indicating a flow around the complex, presumably on the western side. All hydrogeological indications are that flow in this area takes place towards Lake Langano, and therefore despite their situation close to the lake they seem unlikely to be deriving a significant amount of water from it.

\section{FLUID-ROCK INTERACTION}

It is apparent from the examples considered above that the significant enrichments in $\delta^{18} \mathrm{O}$ sometimes found in geothermal waters (Ellis and Mahon, 1977) are small or absent in the East African rifts. This indicates that the rock has reached an equilibrium with the isotopic composition of the recharging water, implying a high water:rock ratio. This in turn suggests that the hydrothermal systems may be of some antiquity, because the volume of water required would take a considerable time to pass through a system at the low permeabilities known to exist in the rifts (e.g. Allen and Darling, 1992). This concept of hydrothermal longevity is supported by the existence of high-level hot spring sinter deposits associated with Quaternary pluvials in both the MER and KRV (Gizaw, 1989; Darling et al., 1993; Sturchio et al., 1993).

The effects of fluid-rock interaction are more easily discerned when the $\delta^{13} \mathrm{C}$ content of dissolved inorganic carbon (DIC) is considered. Fig. 11 shows a plot of $\delta^{13} \mathrm{C}_{\mathrm{DIC}}$ versus DIC, expressed as $\mathrm{HCO}_{3}^{-}$, for groundwaters in the KRV and MER. The more depleted $\delta^{13} \mathrm{C}$ values are typical of the dissolution of rock carbonate by soil $\mathrm{CO}_{2}$ under open-system conditions, and accordingly these waters are likely to consist of little-modified meteoric water. Many of the cooler well and spring waters fall into this category, but few of the hot springs. 
The very high $\mathrm{HCO}_{3}$ concentrations seen in most of the thermal waters are undoubtedly the product of silicate hydrolysis. The basis of this is the following reaction, whereby feldspar reacts with water and $\mathrm{CO}_{2}$ :

$$
2 \mathrm{NaAlSi}_{3} \mathrm{O}_{8}+11 \mathrm{H}_{2} \mathrm{O}+2 \mathrm{CO}_{2}=\mathrm{Al}_{2} \mathrm{Si}_{2} \mathrm{O}_{5}(\mathrm{OH})_{4}+2 \mathrm{Na}^{+}+2 \mathrm{HCO}_{3}^{-}+4 \mathrm{H}_{4} \mathrm{SiO}_{4}
$$

This process is aided by the considerable flux of mantle $\mathrm{CO}_{2}$ throughout the rift areas (e.g. Darling et al., 1995; Gizaw, this volume). High concentrations of $\mathrm{HCO}_{3}$ might result from in-situ hydrolysis where groundwater flow is sufficiently slow, or the process might simply have contributed to the chemistry of lakes which periodically became desiccated, accompanied by the deposition of carbonate evaporites (Lake Magadi in the southern KRV represents an extreme case of this, e.g. Jones et al., 1977). Whether the primary or secondary process is responsible for the results from individual sites cannot easily be identified. Both would give rise to DIC with a composition of around $0 \% 0 \delta^{13} \mathrm{C}$. (Marine carbonate, which would also give rise to a similar value, can be ruled out because there has been no marine transgression within the KRV or MER.)

The evolutionary trend depicted in Fig. 11 assumes that water with an initial post-recharge composition of $250 \mathrm{mgl}^{-1} \mathrm{HCO}_{3}$ and $-16 \% \circ \delta^{13} \mathrm{C}_{\mathrm{DIC}}$ progressively acquires either evaporitic or in-situ (bi)carbonate with a typical value of $-1 \%$. There is not necessarily a direct connection with hydrothermal activity, other than that usually the hotter waters are more effective at promoting hydrolysis or at redissolving evaporites. In the MER, a slightly heavier (bi)carbonate source of around $0 \%$ is indicated, presumably as the result of a slightly different balance of processes.

While (bi)carbonate uptake can explain reasonably well the $\delta^{13} \mathrm{C}$ content of most Rift groundwaters, there is an exceptional case from the KRV north of Lake Baringo where samples from two boreholes at Nginyang (C3868 and an un-numbered adjacent well, Fig. 5) plot away from the trend (Fig. 11). The boreholes are both close to the Nginyang River, so the anomaly may be due to leakage from the river. However, while such dilution could account for the observed $\delta^{13} \mathrm{C}$ values of around $-10 \%$, it does not explain why the DIC concentrations remain so elevated. 


\section{CONCLUSIONS}

Previously, subsurface leakage from the fresher Rift lakes was only demonstrable within the vicinity of the lakes from borehole water levels and hydrochemistry. Stable isotopic techniques have shown that the influence of this leakage can be traced for much greater distances. Differences between individual areas in Kenya and Ethiopia illustrate the importance of using $\mathrm{O}$ and $\mathrm{H}$ isotopes as a routine part of hydrogeological surveying. This would greatly assist the production of reliable hydrogeological maps, which are essential for good water resource management strategies whether applied to population, agricultural or geothermal development.

The scant evidence for hydrothermal oxygen isotope shifting is a sign of geothermal system longevity, and therefore of some importance to studies of system maturity. By contrast, evidence from carbon stable isotopes indicates that the vast majority of rift groundwaters, hot or cold, follow a predictable trend of bicarbonate uptake as a result of fluid-rock interaction in the form of silicate hydrolysis. This trend can be followed from dilute, post-recharge conditions to highly-evolved alkaline groundwaters. However, the extent to which recycling may occur via carbonate evaporites remains unknown.

Acknowlegments - The authors thank colleagues in the Ethiopian Institute of Geological Surveys, Kenya Power and Light Company and British Geological Survey for their assistance with sample collection and analysis. BG and WGD publish with the permission respectively of the Directors of the Ethiopian Institute of Geological Surveys and the British Geological Survey (NERC). 


\section{REFERENCES}

Allen, D. J. and Darling, W. G. 1992. Geothermics and hydrogeology of the Kenya Rift Valley between Lake Baringo and Lake Turkana. Brit. Geol. Surv. Research Rep., $\mathrm{SD} / 92 / 1$.

Coleman, M. L., Shepherd, T. J., Durham, J. J., Rouse, J. E. and Moore, G. R. 1982. Reduction of water with zinc for hydrogen isotope analysis. Anal. Chem., 54, 993995.

Craig, H., Lupton, J. E. and Horowitz, R. M. 1977. Isotopic geochemistry and hydrogeology of geothermal waters in the Ethiopian Rift Valley. Scripps Inst. Oceanog. Rep. 77-14

Darling, W. G., Allen, D. J. and Armannsson, H. 1990. Indirect detection of outflow from a Rift Valley Lake. J. Hydrol. 113, 297-305.

Darling, W. G., Allen, D. J. and Spiro, B. 1993. Oxygen isotopes in relict sinters as a palaeoindicator of Rift Valley climate. In Isotope Techniques in the Study of Past and Current Environmental Changes in the Hydrosphere and the Atmosphere, Proc. Symp. IAEA, Vienna, 555-559.

Darling, W. G., Griesshaber, E., Andrews, J. N., Armannsson, H. and O'Nions, R. K. 1995. The origin of hydrothermal and other gases in the Kenya Rift Valley. Geochim. Cosmochim. Acta. 59, 2501-2512.

Ellis, A. J. and Mahon, W. A. J. 1977. Chemistry and Geothermal Systems, Academic Press, 392pp.

Epstein, S. and Mayeda, T. K. 1953. Variations of the $\mathrm{O}^{18}$ content of waters from natural sources. Geochim. Cosmochim. Acta. 4, 213-223.

Gizaw, B. 1989. Geochemical investigation of the Aluto-Langano geothermal field, Ethiopian Rift Valley. M. Phil. dissertation (unpubl.), Univ. Leeds, U.K.

Gizaw, B. This volume. The origin of sodium bicarbonate and fluoride in the waters from the Main Ethiopian Rift Valley, East African Rift System. J. Afr. Earth Sci. 
Jones, B. F., Eugster, H. P. and Rettig, S. L. 1977. Hydrochemistry of the Lake Magadi basin, Kenya. Geochim. Cosmochim. Acta, 44, 53-72.

Sikes, H. L. 1935. Notes on the hydrology of Lake Naivasha. J. East Afr. and Uganda Nat. Hist. Soc., 13, 74-89.

Sturchio, N. C., Dunkley, P. N. and Smith, M. 1993. Climate-driven variations in the geothermal activity in the northern Kenya Rift Valley. Nature, 362, 233-234.

WRAP (Water Resource Assessment Project). 1987. Water resource assessment study in Baringo District. Water Res. Assessment Div. Rep. Ministry of Water Development, Nairobi, Kenya. 
Table 1 Stable isotopic data for the Naivasha area, Kenya. B - supply borehole, G - geothermal well, L - lake.

\begin{tabular}{lcrr}
\hline Site & $\begin{array}{c}\text { Sample } \\
\text { type }\end{array}$ & $\begin{array}{c}\boldsymbol{\delta}^{18} \mathrm{O} \\
\% \text { \%o }\end{array}$ & $\begin{array}{r}\boldsymbol{\delta}^{2} \mathbf{H} \\
\%\end{array}$ \\
\hline Naivasha & L & +6.6 & +36 \\
C4178 & B & -4.1 & -24 \\
C5002 & B & -4.4 & -22 \\
OW-2 & G & +2.1 & +3 \\
OW-5 & G & +3.7 & +18 \\
OW-16 & G & +3.1 & +10 \\
OW-21 & G & +2.8 & +8 \\
OW-22 & G & +2.7 & +13 \\
OW-23 & G & +3.6 & +13 \\
OW-26 & G & +2.6 & +11 \\
OW-703 & G & +4.5 & +34 \\
OW-705 & G & +3.7 & +25 \\
OW-706 & G & +2.2 & +21 \\
OW-715 & G & +1.0 & +4 \\
EW-1 & G & -2.1 & -9 \\
& & & \\
\hline & & &
\end{tabular}


Table 2 Stable isotopic data for the Awasa-Corbetti area, Ethiopia. B - supply borehole, $\mathbf{F}$ - fumarole, $\mathbf{L}$ - lake, $\mathbf{T}$ - temperature gradient borehole.

\begin{tabular}{lcrr}
\hline Site & $\begin{array}{c}\text { Sample } \\
\text { type }\end{array}$ & $\begin{array}{c}\boldsymbol{\delta}^{18} \mathrm{O} \\
\%\end{array}$ & $\begin{array}{r}\boldsymbol{\delta}^{2} \mathbf{H} \\
\%\end{array}$ \\
\hline Awasa & $\mathrm{L}$ & +7.8 & +53 \\
Shashemane & $\mathrm{B}$ & -2.1 & -1 \\
CTG-2 & $\mathrm{T}$ & -1.1 & -7 \\
CTG-3 & $\mathrm{T}$ & +3.3 & +26 \\
CTG-7 & $\mathrm{T}$ & +3.0 & +30 \\
Borama & F & -2.5 & -5 \\
Chebicha & F & -4.9 & -31 \\
Danshe & F & -5.0 & -29 \\
Koka & F & -2.1 & -9 \\
& & & \\
\hline
\end{tabular}

${ }^{1}$ data of Craig et al. (1977) 
Table 3 Stable isotopic data for the Aluto-Langano area, Ethiopia. F - fumarole, G - geothermal well, $\mathrm{L}$ - lake, S - cool spring, T - temperature gradient borehole.

\begin{tabular}{|c|c|c|c|}
\hline Site & $\begin{array}{c}\text { Sample } \\
\text { type }\end{array}$ & $\begin{array}{c}\delta^{18} \mathrm{O} \\
\% o\end{array}$ & $\begin{array}{r}\delta^{2} \mathbf{H} \\
\% o\end{array}$ \\
\hline Langano & $\mathbf{L}$ & +7.0 & +53 \\
\hline Zwai & $\mathbf{L}$ & +6.7 & +49 \\
\hline E Escarpment ${ }^{1}$ & $\mathrm{C}$ & -3.5 & -13 \\
\hline LTG-30 & $\mathbf{T}$ & -1.2 & +4 \\
\hline LTG-32 & $\mathbf{T}$ & -0.8 & +3 \\
\hline LA-3 & $\mathbf{G}$ & -2.8 & -11 \\
\hline LA-4 & G & -1.4 & -8 \\
\hline LA-6 & G & -1.3 & -13 \\
\hline LA-8 & $\mathbf{G}$ & -2.6 & -7 \\
\hline Auto & $\mathbf{F}$ & -6.1 & -36 \\
\hline Bobessa & $\mathbf{F}$ & -5.7 & -29 \\
\hline Gebiba & $\mathbf{F}$ & -6.2 & -31 \\
\hline Aluto $\mathbf{1 8}^{1}$ & $\mathbf{F}$ & -7.7 & -32 \\
\hline
\end{tabular}

${ }^{1}$ data of Craig et al. (1977) 


\section{FIGURE CAPTIONS}

Fig. 1 Lakes (italics) and late-Quaternary volcanic centres (upper case) of the East African Rift Valley in Kenya and Ethiopia.

Fig. 2 Lake Naivasha and the Eburru, Olkaria, Longonot and Suswa volcanic centres, southern Kenya. The location of the Olkaria East geothermal wellfield and individual wells of the Olkaria Northeast and Eburru wellfields are shown. The numbers 3, 5, 6 and 15 refer to wells OW-703, 705, 706 and 715, while $\mathrm{E}$ refers to EW-1.

Fig. 3 Plot of $\delta^{2} \mathbf{H}$ vs. $\delta^{18} \mathrm{O}$ for waters in the Naivasha area (data from Table 1). Wells with identifiers are in the Northeastern wellfield, except for $\mathbf{E}$ (Eburru EW-1). Wells without identifiers are in the producing Eastern wellfield. The mixing line between rift-side recharge (represented by typical boreholes from east and west of Naivasha) and lake water is also shown.

Fig. 4 Values of $\delta^{2} \mathrm{H}$ and $\delta^{18} \mathrm{O}$ in depth samples from Eburru well EW-1, plotted vs. depth below ground level.

Fig. 5 Map of the area north of Lake Baringo, northern Kenya, showing groundwater potentiometric contours and schematic flow directions (adapted from Allen and Darling, 1992).

Fig. 6 Plot of $\delta^{2} \mathrm{H}$ vs. $\delta^{18} \mathrm{O}$ for waters in the Lake Baringo area (data from Allen and Darling, 1992). The mixing line between rift-side recharge (represented by the average of Lorusio and C3470) and lake water is also shown.

Fig. 7 Map of the Awasa-Corbetti area, Ethiopia, showing the location of temperature gradient (TG) boreholes, fumaroles, groundwater and lakewater sampling sites. 
Fig. 8 Plot of $\delta^{2} \mathrm{H}$ vs. $\delta^{18} \mathrm{O}$ for waters in the Awasa-Corbetti area (data from Table 2). A - Awasa, B - Borama, C - Chebicha, D - Danshe, K - Koka. The approximate position of the parent water of $B$ and $K$ is marked (+). The mixing line between rift-floor recharge and lakewater is also shown. The water in TG-2 may have been slightly enriched by steam loss.

Fig. 9 Map of the Aluto-Langano volcanic complex, Ethiopia, situated between Lakes Zwai and Langano, showing the location of geothermal wells, temperature gradient boreholes, fumaroles, cool spring and lakewater sampling sites.

Fig. 10 Plot of $\delta^{2} \mathrm{H}$ vs. $\delta^{18} \mathrm{O}$ for waters of the Aluto area (data from Table 3). $\mathrm{L}$ - Langano, $\mathrm{Z}$ - $\mathrm{Z}$ wai. The mixing line between rift-side recharge and lakewater is shown. Minor $\delta^{18} \mathrm{O}$ shifting may be affecting the water in wells LA-4 and LA-6.

Fig. 11 Plot of $\delta^{13} \mathrm{C}_{\text {DIC }}$ vs (bi)carbonate as $\mathrm{HCO}_{3}$ for cool $\left(<40^{\circ} \mathrm{C}\right.$ ) and hot $\left(>40^{\circ} \mathrm{C}\right)$ groundwaters in the KRV and MER. The model line shows the expected trend for bicarbonate uptake (see text). 


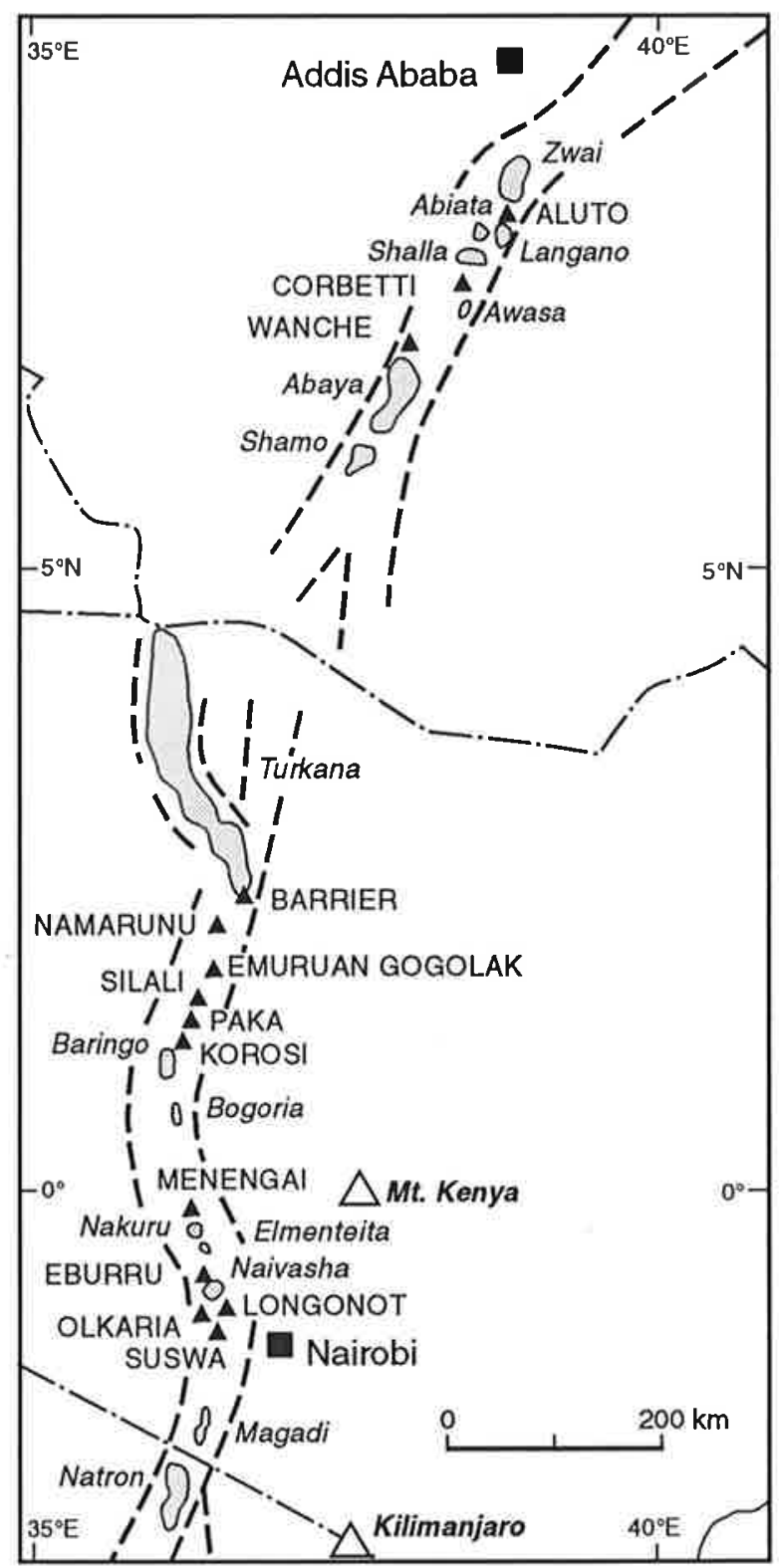

Dorlange et al Fij ' 


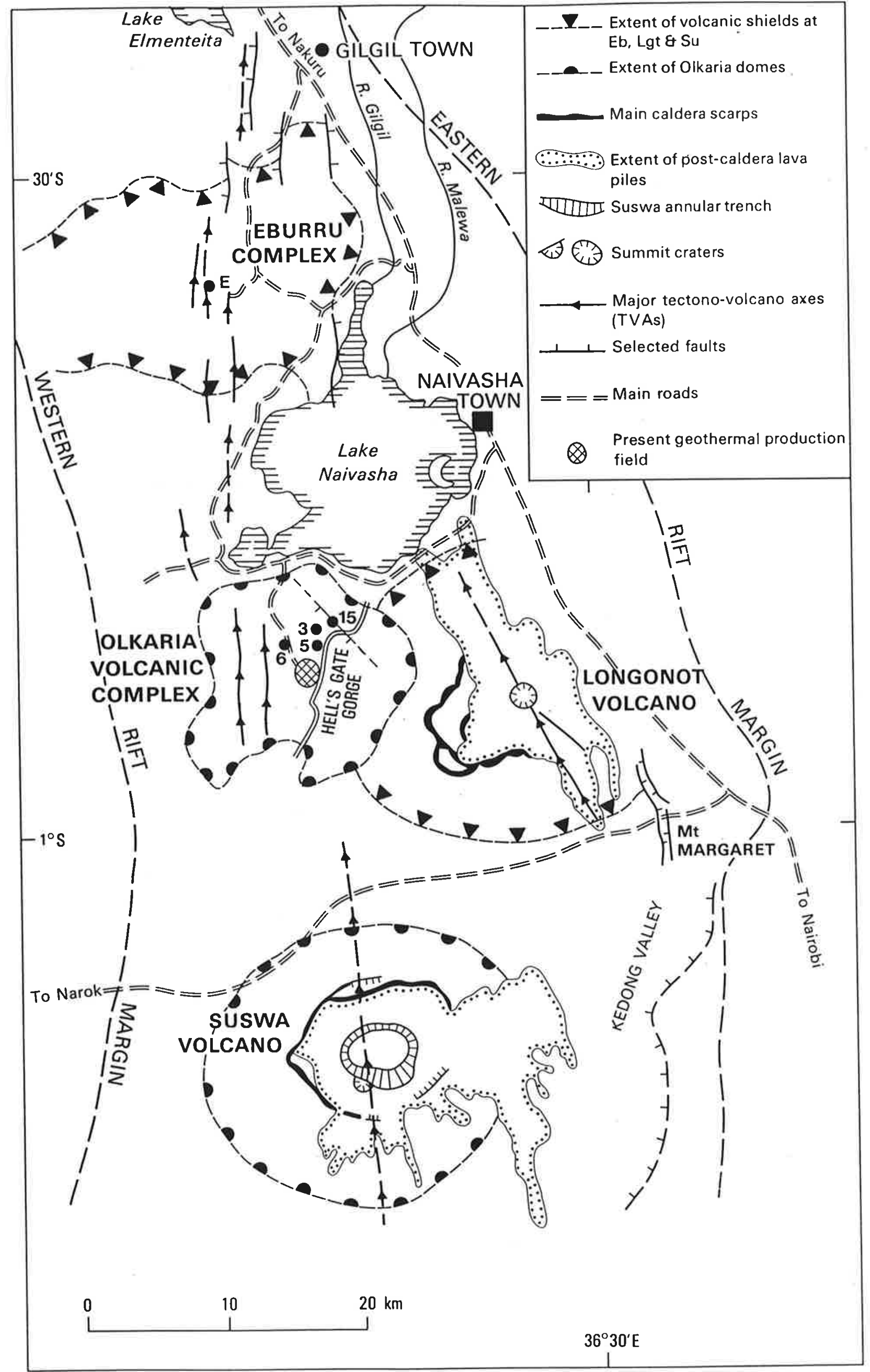




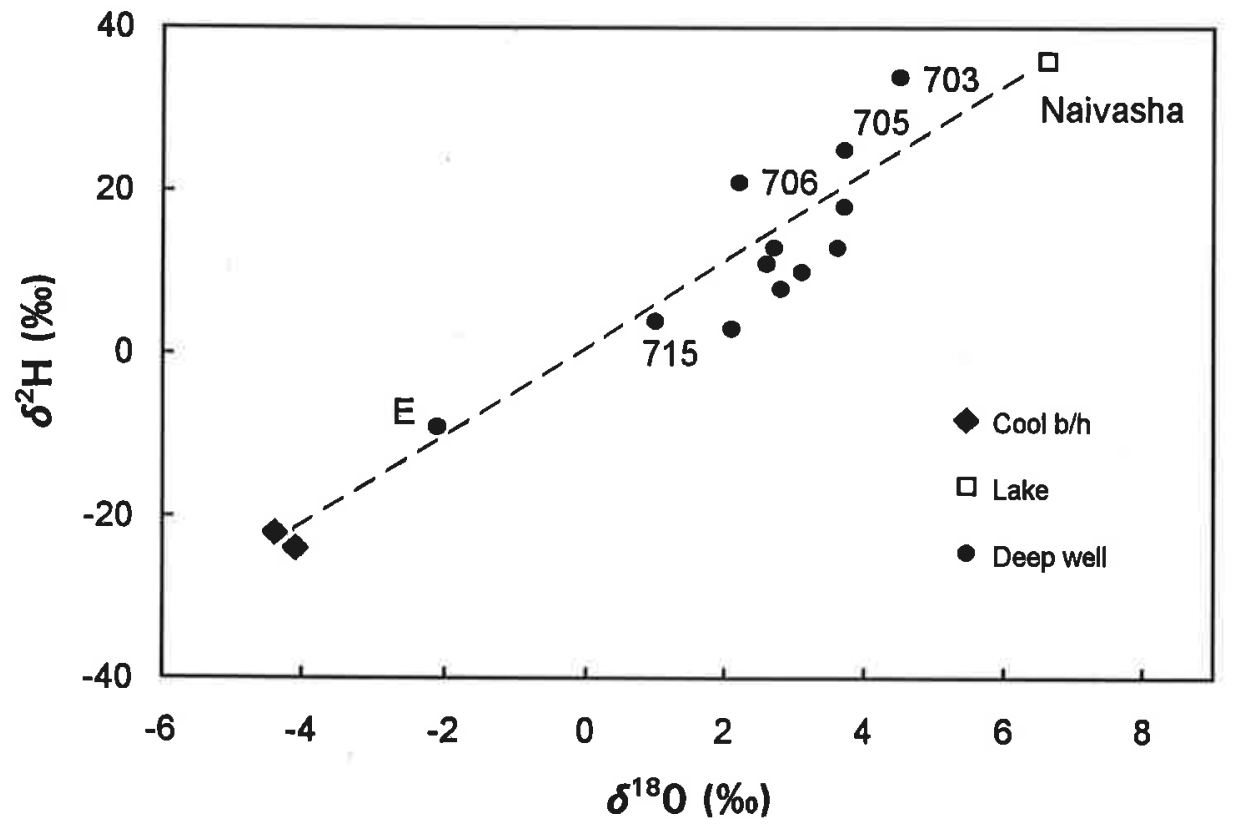

DARLING et al Fig 3 


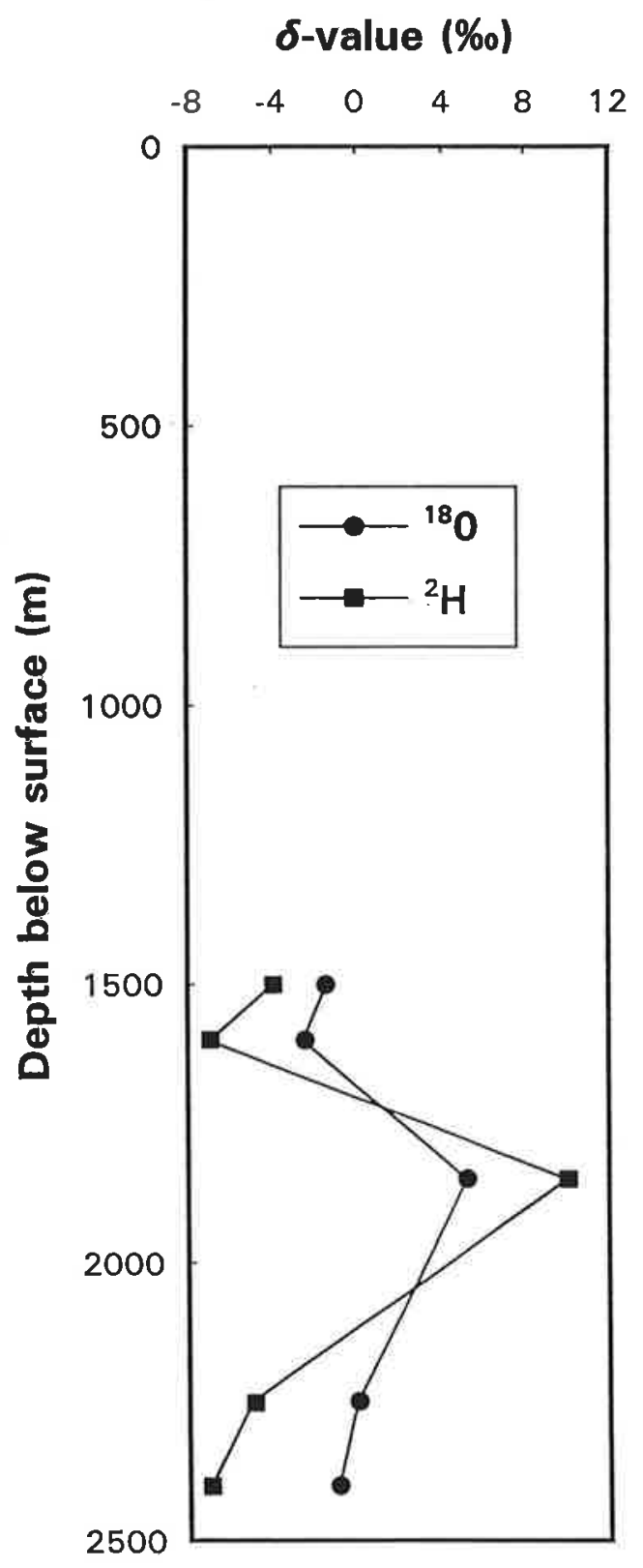

Darcunke at al Fin 4 


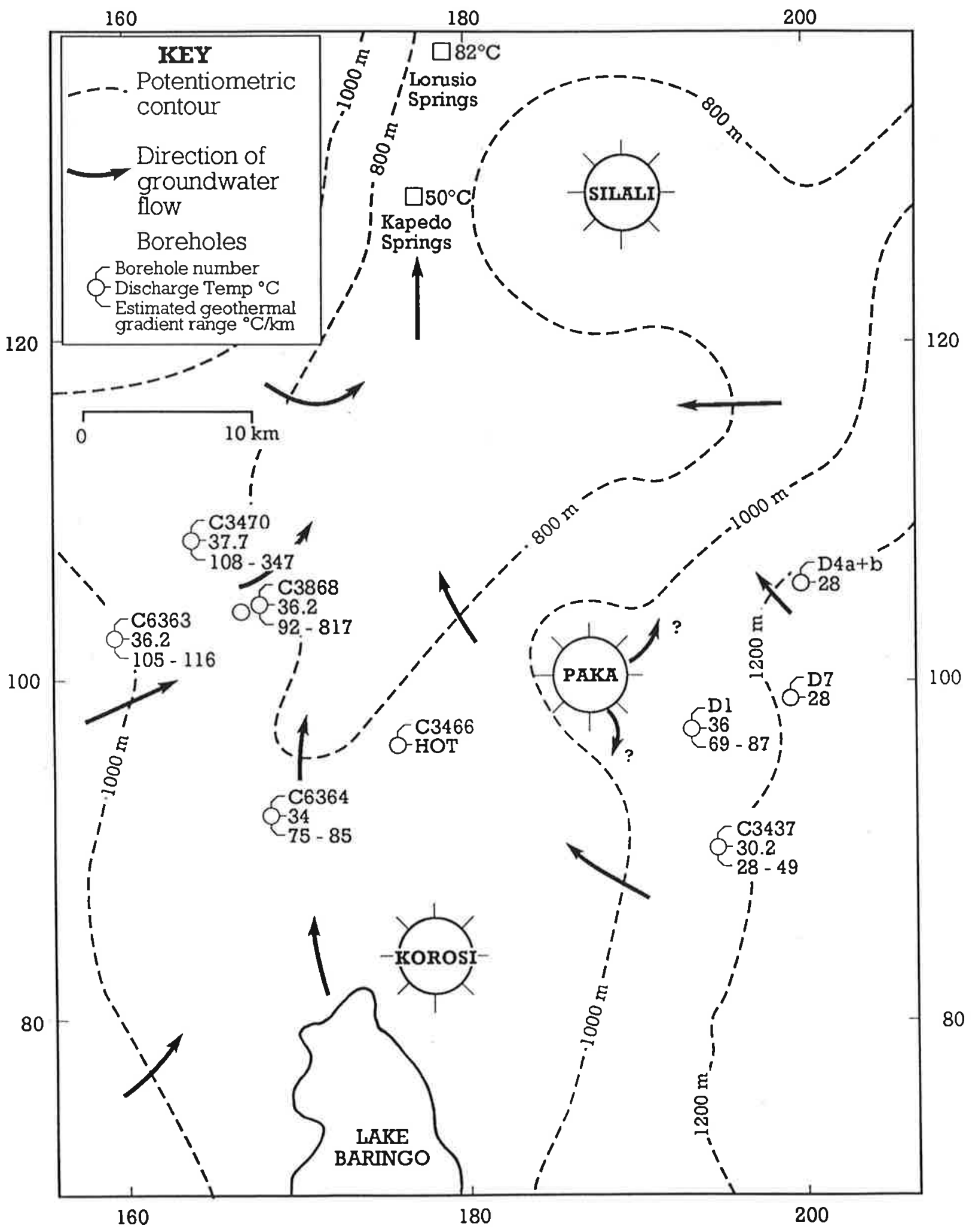

DARlinge at al fiy 5 


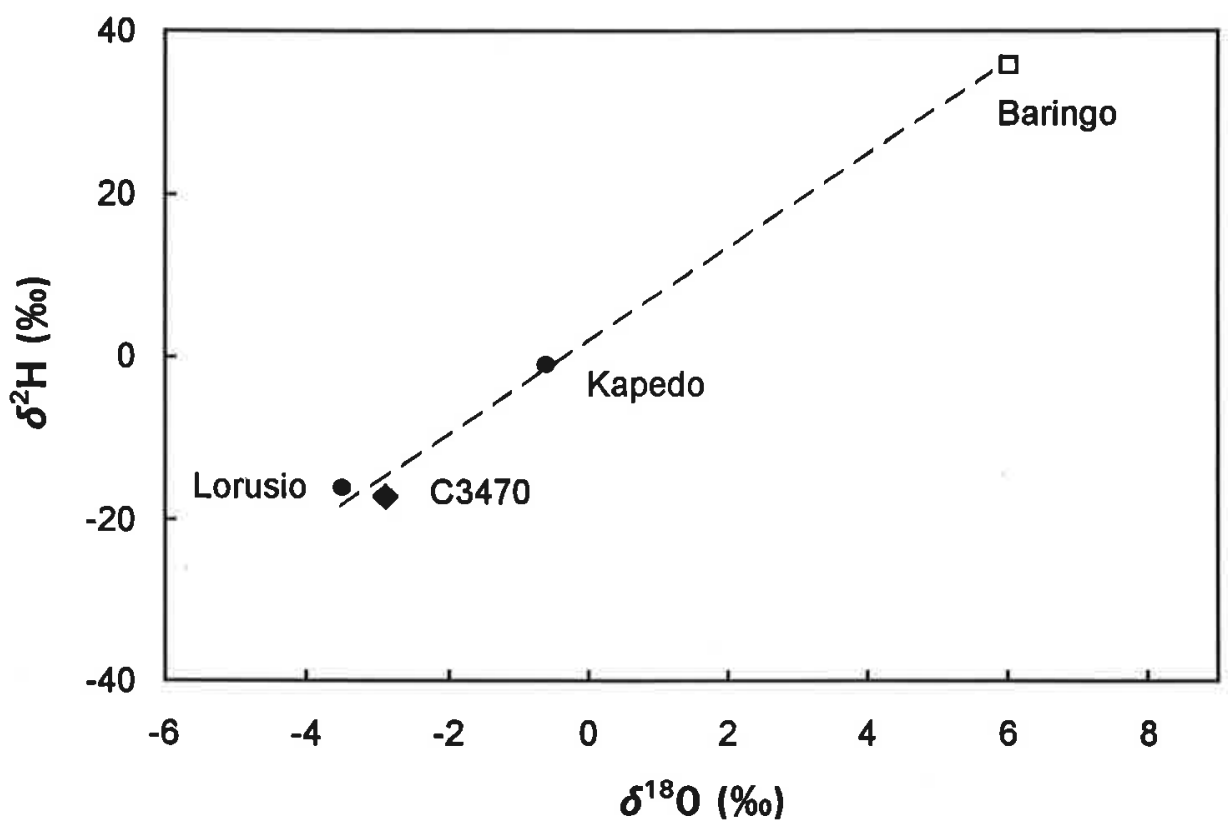

DARLINGe et al Fig 6 


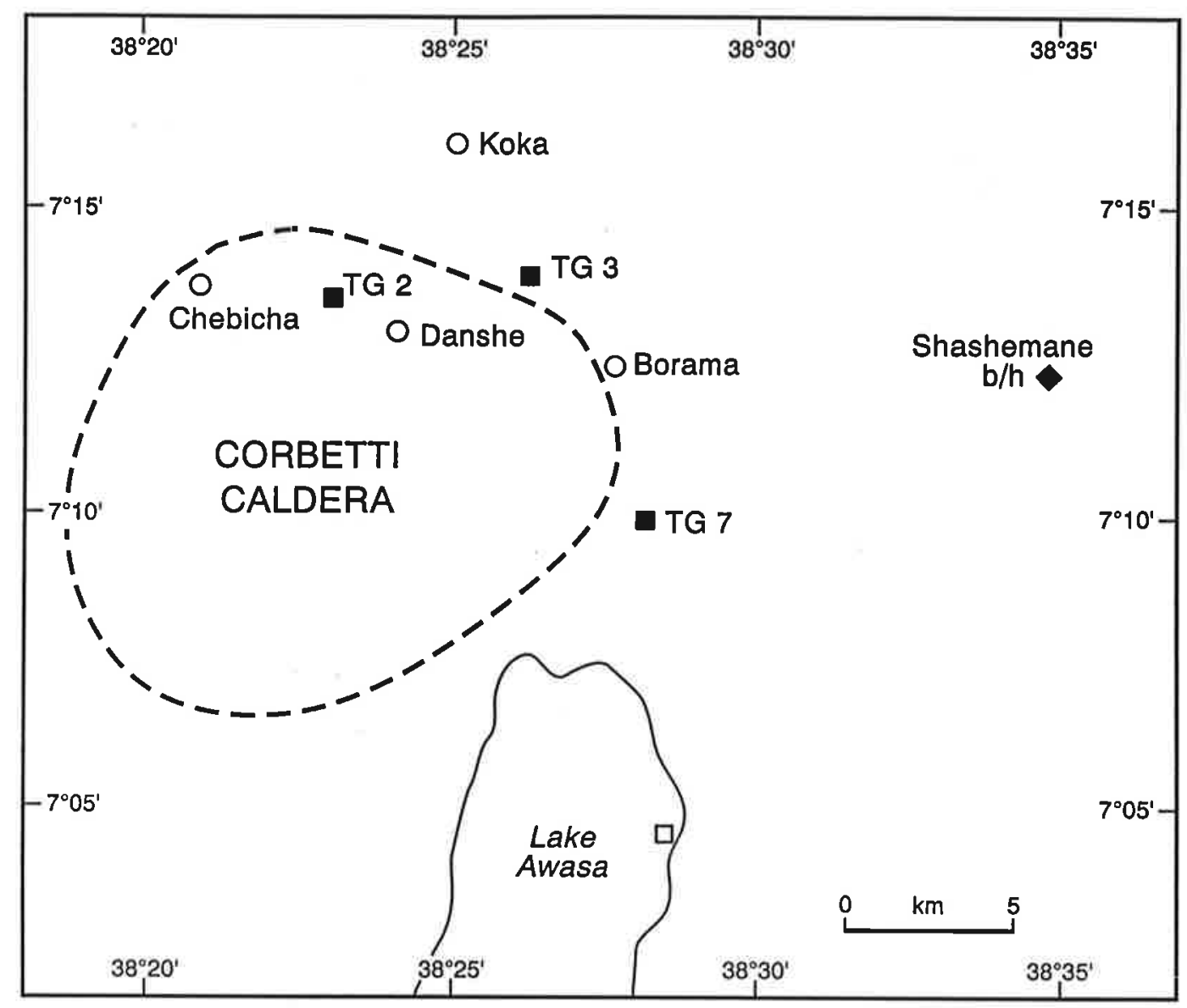

DARuinge et al Fig 7 


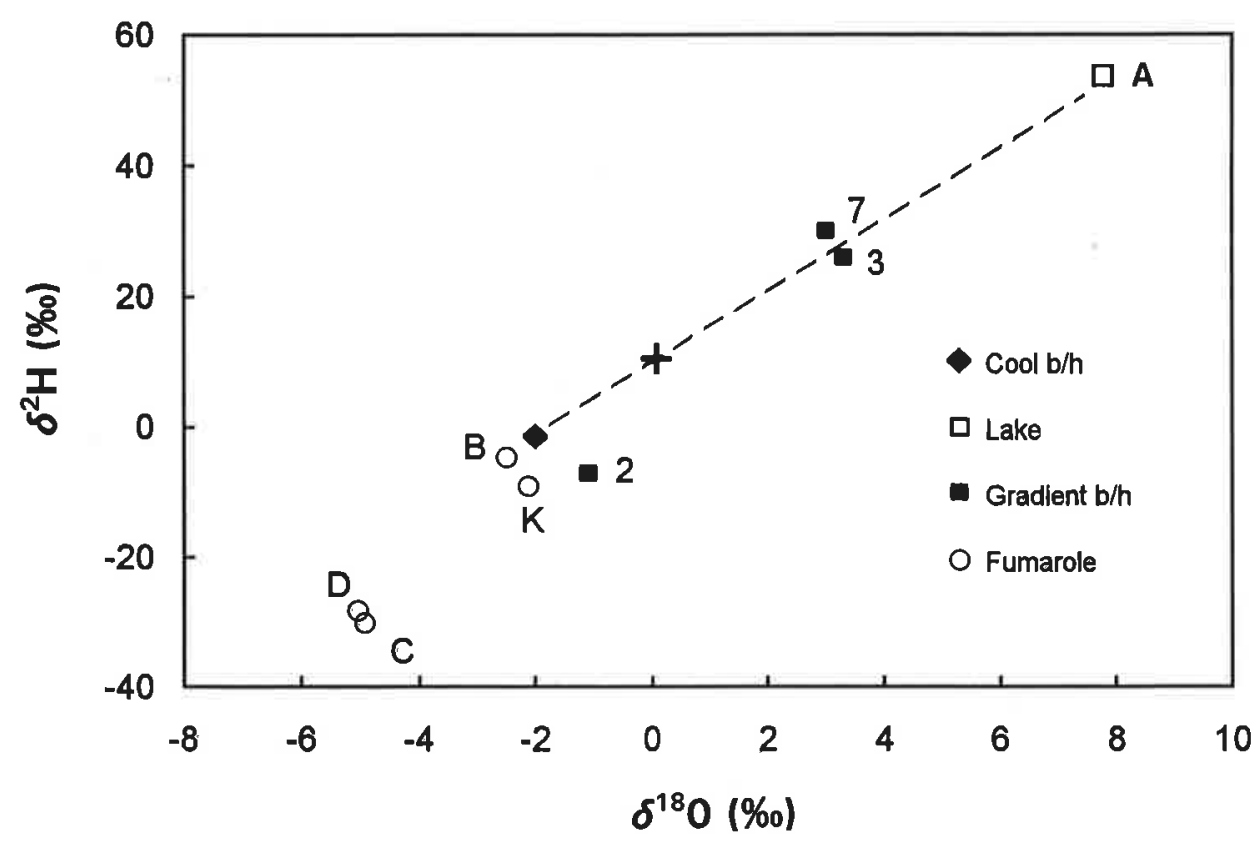

Darling et al Fig 8 


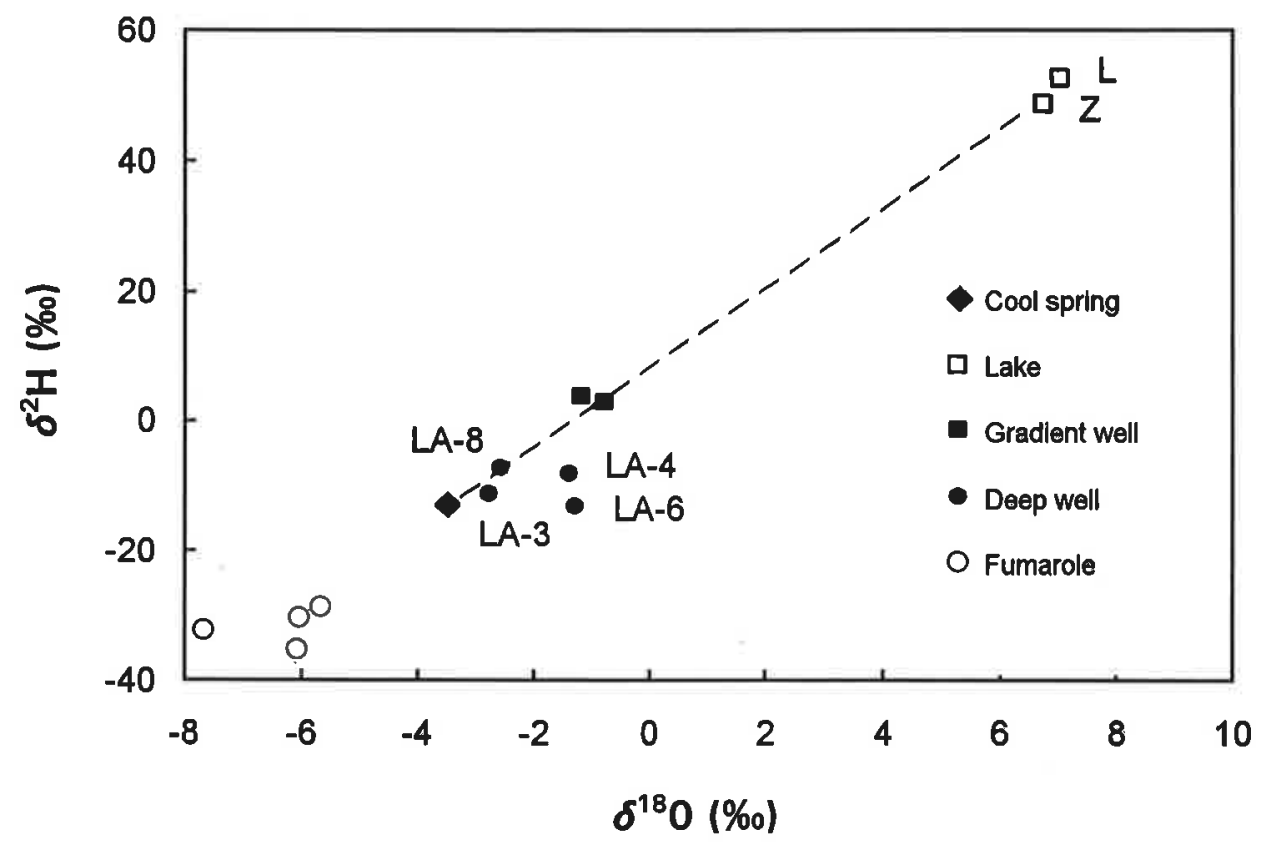

darlinge et al Fíg 10 


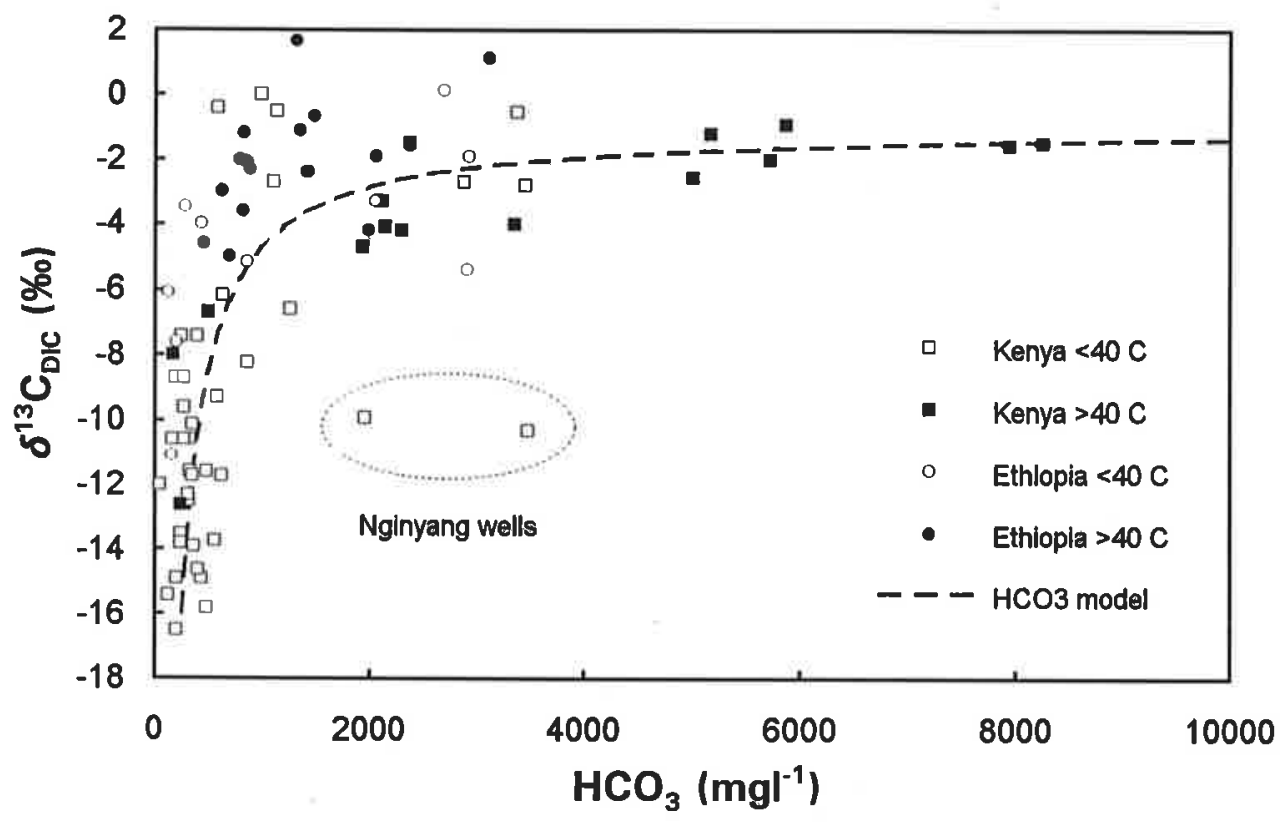

JARLING at al Fig 11 